Ambient Science, 2019: Vol. 06(1); 55-56

DOI:10.21276/ambi.2019.06.1.nn01

ambient

SCIENCE

Vol. 06(1):55-56

Year 2019

NOTES ON NATURAL HISTORY

\title{
Location Study of Some Birds Earlier not Detected from Bastar District of Central India
}

\author{
Sushil Kumar Dutta ${ }^{1 *}$ P.R.S. Nagi ${ }^{2}$, Ravi Naidu ${ }^{3}$, \\ 'Department of Zoology, Govt. P.G. College, Jagdalpur,Bastar, \\ Chhattisgarh,India \\ ²Vetinary Disease Investigation Laboratory, Jagdalpur, Bastar, \\ Chhattisgarh, India \\ ${ }^{3}$ Crow Foundation, Jagdalpur, Bastar, Chhattisgarh, India
}

Study Area:Jagdalpur, Bastar, Chhattisgarh, India

Coordinated: $80.5^{\circ}-82.1^{\circ}$ E and $18.4^{\circ}-19.9^{\circ} \mathrm{N}$

Key words: River Lapwing, Marsh Sandpiper, Crested Bunting, Curlew Sandpiper, Black Stork and Common Buzzard.

\section{Introduction:}

The avifaunal study in Bastar district of Chhattisgarh spans over thirty years signifies an increase in diversity. Present study is further addition to the avifaunal diversity of Bastar district of Chhattisgarh. The author-1 had documented and reported 319 species within a time span of thirty years (Dutta, 2017). Possibly the birds have been recorded for the first time from these areas were either visiting here for the first time or are the regular visitors, but escaped from our sight. Many of such sites are abode to numerous resident/migratory as well as rare birds. This report is for inventory of six new birds sighting from the Bastar district. One rare bird is the first record for Central India; while o5 other records are new to Bastar district.

\section{Surveyed area:}

We covered an area of $4,029.98 \mathrm{Km}^{2}$ of newly demarcated Bastar district during which we visited some of the new areas, not approached earlier and revisiting the areas on regular basis for recording avifaunal diversity and for any possible new species and re-encounters of species during 01/01/2018 to 31/12/2018. For proper identification, we followed Ali \& Ripley (1968-1974), Grimmett et al. (2011), Kazmierczak (2012); Naoroji (2011). All the followed common names are based on Praveen et al. (2016).

\section{Our sighting records:}

a) River Lapwing Vanellus duvaucelii: a single River Lapwing was sighted on 30/10/2018 in the evening near a pond and was also re-sighted in next morning $01 / 11 / 2018$ on the same spot in Rajnagar village about $26 \mathrm{~km}$ north of Jagdalpur town. The water-body is surrounded by cultivated fields. The south-western side has a small area of degraded forest. The tank is free from of macrophyte growth. This sighting was the first record for Bastar district as well as the first record for Central India (Madhya Pradesh and Chhattisgarh) (Plate-1a). It is winter migrant and categorized as Near Threatened as per status of IUCN Red List Data.
Simultaneously, it was also sighted from January to June 2018 and was re-sighted in December 2018 along the Mahanadi river bed on stony and bouldered part near to historical Sirpur village which is $35 \mathrm{~km}$ away from Mahasamund city of Chhattisgarh (Jageshwar Verma, pers. Comm., 2019). This is the closest distribution record with c.f. the distance of $234 \mathrm{~km}$ from the present locality.

(b) Marsh Sandpiper Tringa stagnatilis: a single Marsh Sandpiper was sighted in November 2017 near a pond of Tarapur, Bajawand and in November 2018 near a pond of Jamawada. This sighting is first record for Bastar district (Plate: $1 b)$. It is winter migrant and categorized as Least Concern as per status of IUCN Red List Data.

(c) Curlew Sandpiper Calidris ferruginea: two Curlew Sandpipers were spotted in November 2013 but could not be identified properly due to poor light conditions. Fortunately, it was again spotted in the month of November 2018 near Rajnagar pond. It is the first record for Bastar district (Plate: 1c) and a winter migrant. It is categorized as NearThreatened as per status of IUCN Red List Data.

(d) Black Stork Ciconia nigra: a solitary Black Stork was spotted in the month of February 2018 and was sighted continuously for the next 7 days. It was sighted on the shallow part of the water body (pond) at Jamawada about 15 $\mathrm{km}$ south of Jagdalpur town. It is the first record from Bastar district (Plate: 1d). Black Stork is a winter migrant and categorized as Least Concern as per status of IUCN Red List Data. It may also be taken on a record that 05 individuals of this species has been sighted from the month of October 2017 to March 2018 and again re-sighted from the October 2018 to December 2018 with a record of maximum 11 individuals in the Janjgir district of the Chhattisgarh (Kumar Singh, pers. comm.). It is the closest distribution record with a c.f. the distance of $338 \mathrm{~km}$ from the present locality.

(e) Crested Bunting Melophus lathami: six Crested Bunting individuals were spotted in the months of January 


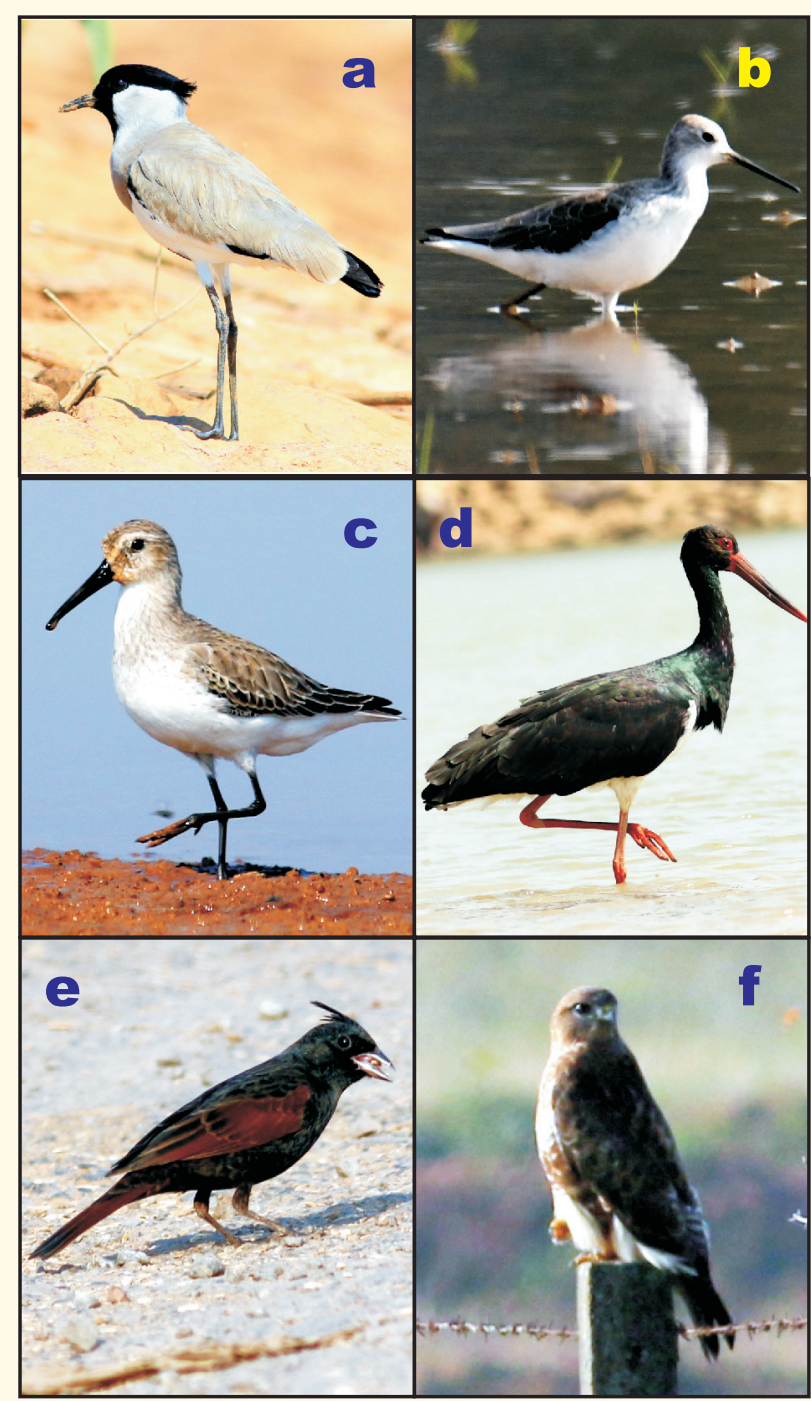

Plate-1:a) River Lapwing; b) Marsh Sandpiper; c) Curlew Sandpiper;

d) Black Stork; e) Crested Bunting; f) Common Buzzard

and February 2018. The group was sighted in the vicinity of Jagdalpur near Rice Mill in a scrub jungle. It was noticeable that this species is sighted near a rice-mill thriving on spilled grain. It is the first record for Bastar district (Plate: 1e). Crested Bunting is resident birds and is categorized as Least Concern as per status of IUCN Red List Data.

(f) Common Buzzard Buteo buteo: a solitary Common Buzzard was spotted in the month of February 2018. It was sighted near a pond at Jamawada. It is the first record for Bastar district (Plate: If). Common Buzzard is a winter migrant and is categorized as Least Concern as per status of IUCN Red List Data.

\section{Remarks:}

Interestingly, out of 56 new records to Bastar district (earlier 50, at present 6), o7 species are the first record for Central India (Dutta, 2017). In this way, the avifaunal diversity of Chhattisgarh goes over to a total of 325 species which accounts to about $25.7 \%$ bird species of India. Taxonomically, it covers o9 orders, 24 families, 44 genera
Table-1: List of birds species (continuating) recorded from Bastar in (Serial number- 51 to 56) from the year 2013- 2018

Place of Sighting \& Abundant Migratory IUCN Record Date of record Frequency Status Status Status

Vanellus duvaucelii, Ord.- Charadriiformes, Fam.- Charadriidae Rajnagar Tank in Nov. '18 $1(\mathrm{R}) \quad$ WM $\quad$ NT $\quad$ FRCI Tringa stagnatilis Ord.-Charadriiformes, Fam.-Scolopacidae Jamawada tank in Nov. '18 1 (R) WM LC New Calidris ferruginea, Ord.-Charadriiformes, Fam.-Scolopacidae Rajnagar Tank in Nov. '13 $2(\mathrm{R}) \quad$ WM $\quad$ NT $\quad$ New \& conf irmed in Nov. '18

Ciconia nigra, Ord.-Pelecaniformes, Fam.-Ciconiidae Jamawada tank in Feb. '18 1 (R) WM LC New Scrub jungles around Rice

Melophus lathami, Ord.-Passeriformes, Fam.-Emberizidae Scrub jungles around Rice Mills in Jan. \& Feb. '18 6 (R) RS LC New Buteo buteo, Ord.-Accipitriformes, Fam.-Accipitridae $\begin{array}{lllll}\text { Jamawada tank in Feb. } 18 & 1(\mathrm{R}) & \mathrm{WM} & \mathrm{LC} & \mathrm{New}\end{array}$ Ord.-Order, Fam.- Family Abundance: R: Rare (1-3 encounter); UC: Uncommon (4-6 seen); C:Common (7-10 seen);A:Abundant (>10 seen).

Migratory status: RS: Resident; WM: Winter Migrant; SM: Summer Migrant; PM: Passage Migrant

Record Status: New- First record to Bastar District, FRCI- First Record to Central India (Madhya Pradesh and Chhattisgarh), RSPrevious record with recent sighting (Re-sighting).

and 56 species of avifauna respectively. Table-1, highlighting the habitat type, local status and abundance.

Conclusively, the survey identifies the avifaunal diversity and potential areas for bird conservation within the district of Bastar. It would provide baseline information for further studies related to avifaunal conservation.

Acknowledgements:

We thanks Dr. Muntaz Khan, Dr. M.L.Naik, Prof. V.C. Awasthi, for helping in identification of birds, preparation of the manuscript.

\section{References:}

Ali, S. \& Ripley, S.D. (1968-74): Handbook of the Birds of India \& Pakistan (1o Vols.).Pub. by: Oxford University Press.

Dutta, S.K., (2017): Avifaunal Diversity and Conservation Status in Bastar District of Chhattisgarh, India: An Update. Ambient Sci., 04(2):31-35.

Grimmett, R., Inskipp, C. \& Inskipp, T. (2011): Birds of the Indian subcontinent. Pub. by: Oxford University Press. pp. 384.

Kazmierczak, K. (200o): A field guide to the birds of India, Sri Lanka, Nepal, Bhutan, Bangladesh, and the Maldives. Pub. by: Om Book Service, India. PP. 352.

Naoroji, R. (2011): Birds of Prey of the Indian Subcontinent. Pub. by: Om Books International, India. PP. 692.

Praveen, J., Jayapal R., \& Pittie, A. (2016): A checklist of the birds of India, Indian BIRDS, 11 (5\&6):113-172. 